\title{
A General Perspective of Online Learning during Pandemic COVID-19: A Case Study in Chakdaha Block, West Bengal, India
}

\author{
Bibhas Guha $^{1}$, Biswajit Mandal ${ }^{2}$ and Dhrubajyoti Chattopadhyay ${ }^{3}$ \\ ${ }^{1}$ Assistant Professor, Dept. of Zoology, Netaji Subhas Open University, West Bengal, India \\ ${ }^{2}$ Assistant Professor, Dept. of Geography, ${ }^{3}$ Associate Professor, Dept. of Commerce, \\ Nahata J. N.M. S. Mahavidyalaya, West Bengal, India \\ E-mail: bmgeo1981@gmail.com
}

\begin{abstract}
Considering education is the prerequisite for human development, World Education Forum (1990) declared that provisions should be made for educating all people. The Government of India has already ensured free and compulsory education to all children within the age group between 6 and 14 under Article 21A of the Indian Constitution (The Right to Education Act, 2009). In 2006, the Government of India has introduced online learning in rural and urban areas as a purview of propagating education. Online learning is the electronic education process by which a learner can learn effectively. Now-a-days, it seems to be a useful tool for upgrading and propagating education throughout the globe. Report depicts that internet access in rural India is nearly $20.26 \%$, as compared to $64.84 \%$ in urban India, whereas in West Bengal the internet access is estimated as a whole around $11 \%$ (Internet Live Stats, 2016). Lack of infrastructure, hardware facilities, Government policies, strategies and schemes, awareness about online learning material usage, computer based courses, skilled trainers etc. are becoming a hindrance for online learning to rural learners. In this context, the objective of the paper is to evaluate the uses and effectiveness of online learning during Pandemic COVID-19. The implication of the study is discussed through a case study in Chakdaha Block, West Bengal, India.
\end{abstract}

Keywords: COVID-19, Internet Access, Online Learning, Pandemic

\section{INTRODUCTION}

In recent years, people of both developed and developing countries are more concerned about teaching-learning process and its onward application in the field of education. Online learning is the electronic education process by which a learner can teach effectively. The COVID-19 pandemic has changed education forever(URL-1), but Online learning technologies have a remarkable potential of integrating with traditional teaching methods as well as in creating a new dimension in distance education (Ruiz et al; 2006; Berman, 2008).

Apart from formal education, livelihood information regarding governance viz., health awareness programmes, public distribution system, Government supportive schemes etc. are also made available among the people through online learning. Meanwhile, learning process has undergone a sea change-physically classroom learning is converted into ICT based domain of virtual study classroom or smart classroom. Internet facilities along with innovative multimedia technology in respect of online learning make the education more accessible and easier to the learners. In 2006, the Government of India has introduced online learning in rural and urban areas through distance education to ensure education for all. Internet access in rural India is nearly $20.26 \%$, as compared to $64.84 \%$, in urban India, whereas in West Bengal the internet access is estimated as a whole around 11\% (Internet Live Stats, 2016).

Lack of infrastructure, hardware facilities, Government policies, strategies and schemes, awareness about online learning material usage, computer based courses, skilled trainers etc. are becoming a hindrance for online learning to rural learners, particularly in a developing country like India. During COVID-19, learners have been more involved in online learning system as per direction of Education Department in Government of West Bengal under the directive of Ministry of Human Resource Development (MHRD,2020), Government of India. On the other way, Central and State Government introduced various schemes for the welfare of people during this time. In this context, this paper proposes to evaluate the uses and effectiveness of online learning during pandemic COVID-19 among the people in respect of propagation of both governance and formal education.

In this paper, existing online system was utilized to disseminate the information gathered from the Government regarding governance viz., health awareness and public distribution system to the people staying at home and also propagating online learning among the students in Chakdaha Block, Nadia, West Bengal during pandemic COVID-19.

\section{OBJECTIVES OF THE STUDY}

The study has the following objectives:

1. To build a new frame work of online learning during COVID-19 in the study area;

2. To examine the application of online leaning during COVID-19 in the study area. 


\section{METHODOLOGY OF THE STUDY}

For conducting of the study 100 polling stations (locally called as booth) from the Chakdaha Block were randomly selected in the first stage. In the second stage, one general respondent and one student respondent were selected from each polling station to create two whatsapp broadcast groups, which was handled by the authors as admin.

Therefore, there were total sample size of 100 for general respondents and 100 for student respondents aligned into two different whatsapp group. There was another whatsapp group where admins was clubbed together to exchange their opinions and views. A schematic diagram for the proposed study has been presented in the following;

Whatsapp broadcast group with general respondents (whatsapp group-I) were utilized for sending different livelihood information of the Government regarding governance viz., health awareness programmes, public distribution system, Government supportive schemes etc.

In the selected polling stations and also to collect the feedback from the general respondents during COVID-19 and thereafter transmits the information to the local administrators like Block Development Officer, Hospital Superintendent and Panchayat Prodhan.

Whatsapp broadcast group with student respondents (whatsapp group-II) were used to aware the learners regarding online learning programmes which were initiated by different schools in the Chakdaha Block. Special online learning classes on different topics of zoology, commerce and geography were taken for the learners via zoom app, skype as well as YouTube. Moreover, student respondents were suggested to collect information about others learners in the study area who are lying beyond our study. The entire study was conducted for one month duration.

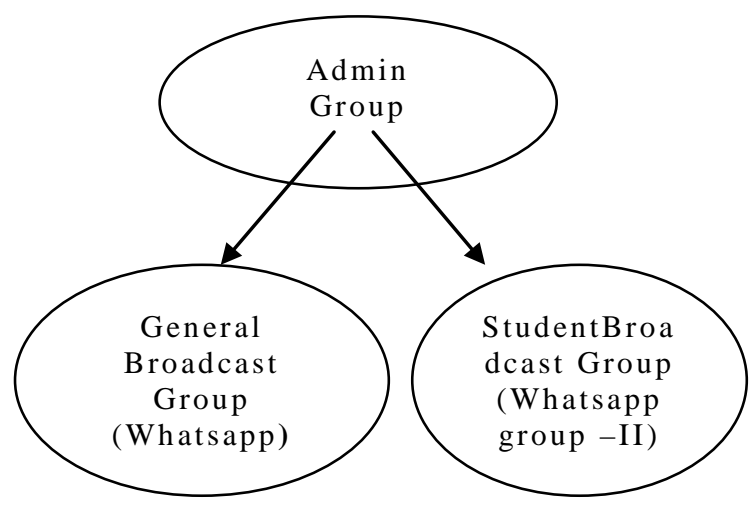

Fig.1 Schematic diagram of the preparation of whats app groups

\section{A GLIMPSE OF CHAKDAHA BLOCK, WEST BENGAL, INDIA}

Chakdaha Block is located in Kalyani Subdivision of Nadia district, West Bengal. It has 17 gram panchayats, 136 villages and 267 polling stations. This block extends from latitude $22^{0} 56^{\prime} 30^{\prime \prime} \mathrm{N}$ to $23^{0} 07^{\prime} 08^{\prime}$ ' $\mathrm{N}$ and longitude $88^{0} 24^{\prime} 30^{\prime \prime} \mathrm{E}$ to $88^{0} 42^{\prime} 06^{\prime \prime} \mathrm{E}$. The $\mathrm{NH}-34$ crosses along Chakdaha block and distance from Kolkata near about 70 $\mathrm{km}$. A glimpse of Chakdaha Block is presented in the following table I.

TABLE I GENERAL INFORMATION ABOUT CHAKDAHA BLOCK, WEST BENGAL, INDIA

\begin{tabular}{|c|c|c|}
\hline \multicolumn{2}{|r|}{ Particulars } & Information \\
\hline \multicolumn{2}{|l|}{ Extension } & $\begin{array}{l}22^{0} 56^{\prime} 30^{\prime \prime} \mathrm{N} \text { to } 23^{0} 07^{\prime} 08^{\prime \prime} \mathrm{N} \\
88^{0} 24^{\prime} 30^{\prime \prime} \mathrm{E} \text { to } 88^{0} 42^{\prime} 06^{\prime \prime} \mathrm{E}\end{array}$ \\
\hline \multicolumn{2}{|l|}{ Area } & 356.25 Sq. km \\
\hline \multicolumn{2}{|l|}{ Population (2011) } & 660495 \\
\hline \multicolumn{2}{|l|}{ Gram Panchayat } & 17 \\
\hline \multicolumn{2}{|l|}{ Village } & 136 \\
\hline \multicolumn{2}{|l|}{ Polling Station } & 267 \\
\hline \multicolumn{2}{|c|}{ Distance from Kolkata } & $70 \mathrm{kms}$ \\
\hline \multicolumn{2}{|c|}{ Distance from Chakdaha city } & $18 \mathrm{kms}$ \\
\hline \multirow{3}{*}{ Health Centre } & State General Hospital & 1 (100 beds) \\
\hline & Primary Health Centre & 4 (10 beds) \\
\hline & Family Welfare Sub Centre & 40 \\
\hline \multirow{5}{*}{ Education Institute } & Primary School & 222 \\
\hline & Upper Primary School & 14 \\
\hline & High School & 39 \\
\hline & Technical Professional Institute & 6 \\
\hline & Institute of Non-Formal Education & 705 \\
\hline
\end{tabular}

Source: District Statistical Handbook, Nadia, 2012 


\section{RESULTS AND DISCUSSION}

Different projects on health awareness programmes, public distribution system, Government supportive schemes etc. published by the Government were sent via the General
Broadcast Group (whatsapp Group-I) to the general respondents during this lockdown period (Table II).

TABLE II VARIOUS GOVERNMENT SUPPORTIVE SCHEMES

\begin{tabular}{|c|l|c|l|}
\hline Sl.No. & Project Name & $\begin{array}{c}\text { Date of } \\
\text { commencement }\end{array}$ & \multicolumn{1}{c|}{ Purpose } \\
\hline 1 & Jai Bangla & $1^{\text {st }}$ April, 2020 & $\begin{array}{l}\text { Provide financial support for 60 years old and above } \\
\text { (SC/ST).The beneficiary will get Rs. 1000/- }\end{array}$ \\
\hline 2 & Sneher Paras & $20^{\text {th }}$ April,2020 & $\begin{array}{l}\text { Provide financial help to the migrate workers (Corona Scheme). } \\
\text { The applicants will get 1000 rupees. }\end{array}$ \\
\hline 3 & Prachesta & $10^{\text {th }}$ April,2020 & $\begin{array}{l}\text { Provide financial support to daily workers. The applicants will } \\
\text { get Rs.1000/-one time ex-gratia. }\end{array}$ \\
\hline
\end{tabular}

A general feedback form was sent to the respondents for getting their opinions to access the performance. The authors recorded the data of the respondents. The satisfaction level of the general respondents is measured in 4 point Likert Scale (Table III).

It was found that $61 \%$ general respondents were highly satisfied followed by $22 \%$ were moderately satisfied and $11 \%$ were satisfied with the livelihood information transmitted in the General Broadcast Group (Whatsapp group I) for the general respondents. It needs to mention that $6 \%$ people were dissatisfied Fig. 2 and table III.
TABLE III SATISFACTION LEVEL OF GENERAL RESPONDENTS

\begin{tabular}{|l|c|}
\hline Satisfaction Level & General Respondents (\%) \\
\hline Highly satisfied & 61 \\
\hline Moderately satisfied & 22 \\
\hline Satisfied & 11 \\
\hline Dissatisfied & 6 \\
\hline
\end{tabular}

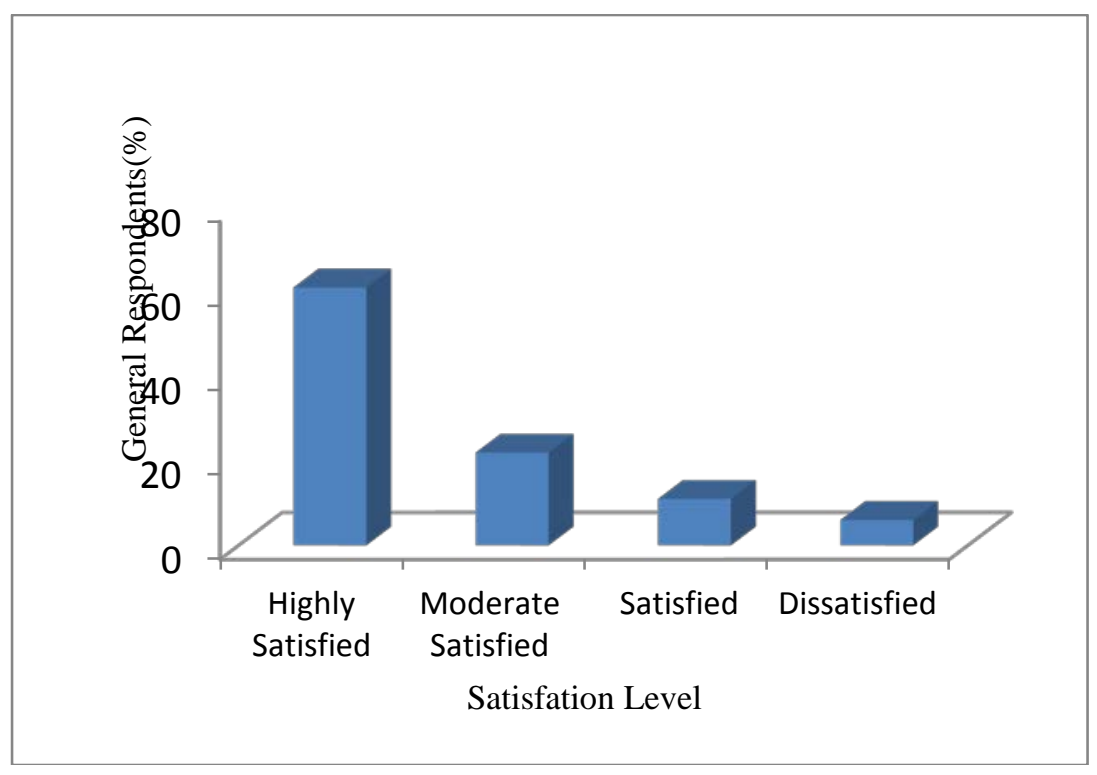

Fig.2 Satisfaction Level of General Respondents

By the application of the online learning system, a high level of response was received from the Student Broadcast Group (Whatsapp Group-II). Both the student and guardians seems to be satisfied by this online learning system.
The guardians were previously in confusion due to lockdown in COVID -19, because students of almost every family have become depressed without schools and their teaching. Through online learning system, the researchers have been able to involve the students with home assignment. 
This is also more important and will be continued till schools open.

It was found that $58 \%$ student respondents were highly satisfied followed by $23 \%$ were moderately satisfied and $12 \%$ were satisfied with the online learning system (Table$\mathrm{IV}$, figure-3).However, 7\% were found to be dissatisfied.

\section{TABLE IV SATISFACTION LEVEL OF STUDENT RESPONDENTS}

\begin{tabular}{|l|c|}
\hline Satisfaction Level & Student Respondents (\%) \\
\hline Highly Satisfied & 58 \\
\hline Moderately Satisfied & 23 \\
\hline Satisfied & 12 \\
\hline Dissatisfied & 7 \\
\hline \multicolumn{2}{|c|}{ Source: Online Survey, March \& April, 2020 }
\end{tabular}

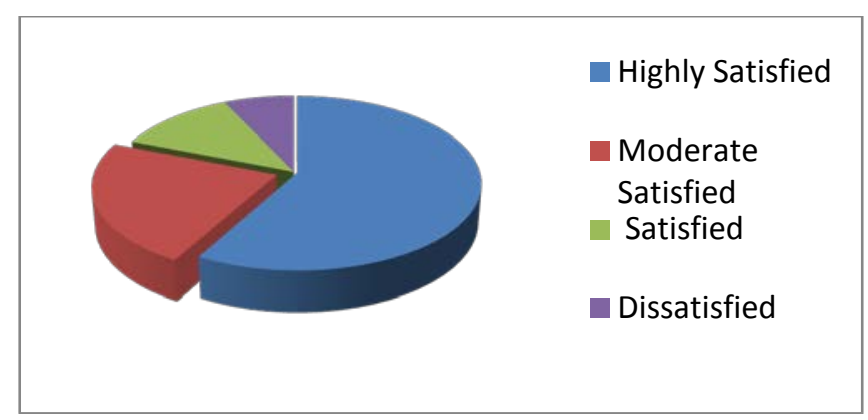

Fig.3 Satisfaction Level of Students

\section{CONCLUSION}

Across the globe, the spread of novel corona virus has led to profound changes in social interaction and organization, and the education sector has not been immune (Weeden and Cornwell, 2020). In this regard during pandemic COVID-19 (till date), online learning has been used as a useful tool for upgrading and propagating formal education as well as disseminating government circular viz., health awareness programmes, public distribution system, Government supportive schemes etc. time to time throughout the study area. Primary data in respect of 200 respondents (100 respondents from general people and 100 respondents from students) through online survey revealed that $61 \%$ general respondents from General Broadcast Group (Whatsapp group-I) are either satisfied or highly satisfied with the livelihood information transmitted to them. It was also found that $58 \%$ student respondents from Student Broadcast Group (Whatsapp group-II) are either satisfied or highly satisfied with the online learning system. The limitation of study is obviously the period of time and selection of small samples (i.e., selection of 200 respondents from 100 polling stations). On the other hand, it is needless to say that in rural area a very lower number of people using internet and or they are lacking proper online access, which also emerges from the study.

Further in depth study is also required to investigate the effectiveness of online learning during Pandemic COVID19 in the study area. But, the authors may propose that online learning could be a major alternative in near future and can become a useful tool during COVID-19.

\section{REFERENCES}

[1] Berman, F.(2006).Making research and education cyber infrastructure real. EDUCAUSE Review, 43 (4),1-16.

[2] Ruiz,J.G., Mintzer, M.J. \& Leipzig, R.M. (2006). The impact of ELearning in medical education. Academic Medicine, 81 (3), 207-212.

[3] Weeden, K., \& Cornwell, B. (2020). The small world network of college classes: implications for epidemic spread on a university campus. Manuscripts under review, http://osf.io/t7n9f (Google scholar).

[4] District Statistical Handbook, Nadia, (2012). Bureau of Applied Economics \& Statistics, Department of Statistics \& Programme Implementation, Govt. of WB.

[5] Ministry of Human Resource Development (MHRD, 2020), Government of India.

[6] Internet Live Stats, 2016 (www.InternetLiveStats.com)

[7] Retrieved from www.wb.gov.in

[8] Retrieved from http://www.weforum.org accessed on $22^{\text {nd }}$ April, 2020. 